\title{
Roles of Toll-like Receptor 7 and 8 in Prevention of Intrauterine Transmission of Hepatitis B Virus
}

\author{
Ting Tian Dandan Sun Peng Wang Hanzhi Wang Xiaoxia Bai Xiaofu Yang \\ Zhengping Wang Minyue Dong
}

Women's Hospital, School of Medicine, Zhejiang University, Key Laboratory of Women's Reproductive Health of Zhejiang Province, Key Laboratory of Reproductive Genetics of the Ministry of Education, Hangzhou, China

\section{Key Words}

Hepatitis B virus • Intrauterine transmission • Placenta • Pregnancy • Toll-like receptor

\begin{abstract}
Background: Approximately 5\% of newborns were infected by hepatitis B virus (HBV) via intrauterine transmission, but most of the infants born to HBV-positive mothers are protected from infection. However, the mechanisms by which intrauterine transmission is avoided remain elusive, and the roles of toll-like receptors (TLRs) have been proposed. The aims of this study were to clarify if TLR 7 and 8 are involved in the prevention of intrauterine transmission of HBV. Methods: Real time polymerase-chain reaction (PCR) was used to determine the expression of TLRs and cytokines in placenta and trophoblasts. The expression of MyD88 was interfered with small interfering RNA (siRNA) in trophoblasts. An in intro model mimicking trophoblast barrier was established to evaluate the effect of MyD88 siRNA on HBV transmission across trophoblast barrier. Results: There were significant differences in placental expression of TLR7 ( $F=3.263, P=0.048)$ and TLR8 ( $F=3.257, P=0.048)$ among control (HBV-negative women), noninfected group (HBV-positive women whose infants were not infected) and infected group (HBV-positive women whose infants were infected). The expression of TLR7 was significantly higher in non-infected group than infected group $(P=0.039)$ and control $(P=0.043)$. There was a significant difference in TLR8 expression between non-infected group and control $(P=0.014)$, and the difference was close to but not significant $(P=0.074)$ between non-infected and infected groups. Exposure of trophoblast to HBV significantly induced the expression of TLR7 $(P<0.001)$, TLR8 ( $P=0.005)$, MyD88 ( $P=0.004)$, interferon (IFN)- $\alpha(P=0.004)$, IFN $-\beta(P<0.001)$ and interleukin (IL)-8 $(P=0.001)$. When MyD88 was interfered by siRNA, the expression of IFN- $\alpha$ $(P<0.001)$, IFN $-\beta(P=0.01)$ and IL-8 $(P<0.001)$ was significantly decreased while the amount of HBV transcytosed across trophoblastic barrier significantly increased $(P=0.03)$. Conclusions: TLR7 and TLR8 on trophoblastic cells play an important role in the prevention of intrauterine HBV transmission by inhibiting HBV translocation across trophoblast.
\end{abstract}

Copyright (C) 2015 S. Karger AG, Basel

Minyue Dong, MD/PhD

KARGER 125
Women's Hospital, School of Medicine, Zhejiang University, Xueshi Road, Hangzhou, Zhejiang Province, 310006, (China)

Tel. +86 5718706 1501, Fax +86 5718706 1878, E-Mail mydong.cn@hotmail.com 


\begin{tabular}{|c|c|c|}
\hline Cellular Physiology & Cell Physiol Biochem 2015;37:445-453 & \\
\hline and Biochemistry & $\begin{array}{l}\text { DOI: 10.1159/000430367 } \\
\text { Published online: August 28, } 2015\end{array}$ & $\begin{array}{l}\text { O } 2015 \text { S. Karger AG, Basel } \\
\text { www.karger.com/cpb }\end{array}$ \\
\hline
\end{tabular}

\section{Introduction}

Hepatitis B virus (HBV) infection is a serious public health problem and chronic HBV infection affects over 350 million people in the world, which leads to a series of liver diseases including chronic hepatitis, fulminant hepatic failure, liver cirrhosis and hepatocellular carcinoma and over one million individuals die annually from these diseases [1]. Intrauterine infection is one of the most important reasons for the high prevalence of HBV infection in endemic regions. It is estimated that intrauterine infection of HBV occurs in $5-10 \%$ of infants of HBV-positive women [2]. Majority of infants of HBV-positive women are not infected via intrauterine route, indicating unexplained mechanisms protect the fetus from intrauterine HBV infection. The mechanisms by which HBV translocates across placental barrier and infects the fetus remain unknown, although it has been evidenced HBV infects trophoblast in vivo and in vitro and this infection is the first and most important step of HBV intrauterine infection $[3,4]$.

Placenta is considered the pregnancy-specific component of innate immune system and comprises the mechanical and immunological barrier restricting microbes from accessing the fetus [5]. Recently, it has been revealed placental trophoblast functions as a macrophage in recognizing and responding to pathogens through the expression of toll-like receptors (TLR) [6-8] and primary placental trophoblasts are more resistant to virus infection than non-trophoblastic cells [9]. The mechanisms by which placental trophoblast combats virus including HBV need elucidating; however, TLRs on trophoblast may play an important role.

TLRs are a family of innate immune receptors that recognize pathogen-associated molecular patterns (PAMPs) expressed by microbes and subsequently mediate an immune response [10, 11]. To date, 10 functional human TLRs have been characterized [10, 11], and their expression is not restricted to immune cells but is also found in a wide range of non-immune cells including placental trophoblast [12]. Following ligand recognition, TLRs activate a common intracellular signaling pathway by recruiting the intracellular signaling adapter protein MyD88. A subsequent kinase cascade triggers the activation of the nuclear factor $\kappa B(N F-\kappa B)$ pathway, which results in the generation of an inflammatory response $[13$, 14].

In the current investigation, it was hypothesized that TLRs on trophoblastic cells is involved in the prevention of intrauterine transmission of HBV. To verify this hypothesis, mRNA expression of TLR7 and TLR8 was first determined in the placenta of HBV-positive and -negative pregnant women. Then, the response of trophoblast to HBV regarding mRNA expression of TLR7 and TLR8 and their down-stream anti-viral cytokines was observed and the effects of TLR-mediated inflammatory response in preventing HBV translocation across placental barrier were evaluated in an in vitro model.

\section{Materials and Methods}

\section{Subjects}

Seven HBV-positive women whose infants were infected via intrauterine transmission composed infected group (infected) and 30 randomly selected HBV-positive women whose infants were not infected comprised non-infected group (non-infected). In addition, $30 \mathrm{HBV}$-negative pregnant women served as control (control).

There were no significant differences in maternal age $(\mathrm{P}=0.675)$, gestational age at delivery $(\mathrm{P}=0.251)$, maternal body weight $(\mathrm{P}=0.933)$, neonatal birth weight $(\mathrm{P}=0.138)$ and neonatal gender $(\mathrm{P}=0.303)$ among three groups (Table 1). Maternal HBV-DNA load $(\mathrm{P}=0.306)$ and the prevalence of HBeAg $(\mathrm{P}=0.606)$ were not significantly different between infected and non-infected groups. HBV-DNA load ranged from 2,400 to 25,700 copies/ml infected neonates. No subjects received anti-HBV drugs.

Chronic maternal HBV infection was diagnosed on the basis of the seropositive hepatitis B surface antigen (HBsAg), the presence of HBV-DNA in maternal serum, normal liver tests and absence of symptoms of acute hepatitis during pregnancy. Intrauterine infection of HBV was defined as the seropositive HBsAg and the presence of HBV-DNA in serum of neonates taken on the third days after delivery. To exclude the possible 


\begin{tabular}{|c|c|c|}
\hline Cellular Physiology & Cell Physiol Biochem 2015;37:445-453 & \\
\hline and Biochemistry & $\begin{array}{l}\text { DOI: 10.1159/000430367 } \\
\text { Published online: August 28, } 2015\end{array}$ & $\begin{array}{l}\text { O } 2015 \text { S. Karger AG, Basel } \\
\text { www.karger.com/cpb }\end{array}$ \\
\hline
\end{tabular}

Table 1. Clinical data

\begin{tabular}{lcccc}
\hline & Control & Non-infected & Intrauterine Infected & $P$ \\
$\mathrm{~N}$ & 30 & 30 & 7 & \\
\hline Maternal age (y) & $29.13 \pm 3.08$ & $28.40 \pm 2.88$ & $28.86 \pm 4.85$ & 0.675 \\
Gestational age (w) & $39.03 \pm 1.13$ & $38.70 \pm 0.79$ & $38.43 \pm 1.27$ & 0.251 \\
Maternal body weight (kg) & $70.07 \pm 6.39$ & $70.62 \pm 8.65$ & $69.57 \pm 8.56$ & 0.933 \\
Primiparity & 29 & 27 & 5 & 0.105 \\
Neonatal birth weight $(\mathrm{g})$ & $3510 \pm 397$ & $3397 \pm 438$ & $3164 \pm 430$ & 0.138 \\
Neonatal gender (F/M) & $15 / 15$ & $19 / 11$ & $3 / 4$ & 0.303 \\
Maternal HBsAg (+) & 0 & 30 & 7 & - \\
Maternal HBeAg (+) & 0 & 18 & 4 & 0.606 \\
Maternal DNA & - & $62.5(22.6,170.3)$ & $67.8(27.4,159.0)$ & 0.306 \\
level $\left(\times 10^{6}\right.$ copies) & & & & \\
\hline
\end{tabular}

effects of labor on the intrauterine transmission of HBV, only mothers with selective Cesarean section were included. The indication for selective cesarean section was maternal HBV infection, breech presentation cephalopelvic disproportion or maternal request. All subjects were negative for serum markers of hepatitis A, C and E. Exclusion criteria included acute HBV infection, presence of pregnancy complications (such as preterm labor, preterm rupture of membrane and preeclampsia), fetal distress, auto-immune diseases, abnormal liver and kidney tests, human immunodeficiency virus (HIV), syphilis, infectious diseases and other diseases.

Standard passive and active immunoprophylaxis strategy was provided for all infants born to HBVpositive mothers. Vaccination strategy included the administration of 100 IU HBIg (human hepatitis B immunoglobing) and HBV vaccine $(5 \mu \mathrm{g})$ within 12 hours of birth. Vaccination series were later completed with two additional doses of HBV vaccine (one at 4 weeks of age and one at 6 month of age).

The protocol of the current investigation was approved by the Ethics Committee of Women's Hospital, School of Medicine, Zhejiang University and the informed consents were obtained from all the participants.

\section{Sample collection}

For the assay of HBV markers, maternal blood samples were taken at the admission to hospital, and neonatal blood samples on the third day after delivery. Blood samples were centrifuged after standing for at least 30 minutes in room temperature and serum was separated. For trophoblastic response test, blood samples were taken from high level HBV carriers (HBV-DNA> $1.0 \times 10^{8}$ copies $/ \mathrm{mL}$ ) with normal liver function test and healthy volunteers with a negative serum HBV marker and serum were separated aseptically. A $0.22 \mu \mathrm{m}$ filtration device (Costar Co., Ltd.) was used for further sterilization. The complement was inactivated at $56^{\circ} \mathrm{C}$ for $30 \mathrm{~min}$ and serum was stored at $-80^{\circ} \mathrm{C}$ until assay.

Placental samples were collected immediately after the placentas were delivered. Placental cotyledons were dissected at middle zone, washed thoroughly with ice-cold normal saline after amniotic membranes, deciduas and connective tissues were removed. They were snap-frozen with liquid-nitrogen, and then stored at $-80^{\circ} \mathrm{C}$ until assay.

\section{Cell culture and HBV exposure test}

Placental trophoblast cell lineage Swan 71 was cultured in DMEM/F12 medium supplemented with $10 \%$ fetal bovine serum and antibiotics (penicillin 100 units $/ \mathrm{ml}$ and streptomycin $100 \mu \mathrm{g} / \mathrm{ml}$ ) at $37 \mathrm{C} / 5 \%$ $\mathrm{CO}_{2}$. Cells were seeded at a concentration of $2 \times 10^{5}$ cells per ml in tissue culture dishes and cultured overnight and then the medium was changed.

When the cells reached a confluence of 50\%-60\%, serum containing high quantity of HBV was added (corresponding to approximately 100 viral genomes equivalent/cell). After 48 hours of incubation, cells were then washed three times with PBS, trypsinized, and collected after extensively washed.

Interference of MyD88

A recombinant lentiviral vector expressing LV-MYD88-RNAi was constructed by Shanghai Genechem (Shanghai, China). LV-MYD88-RNAi was introduced into GV248 RNAi vector that carried the green 


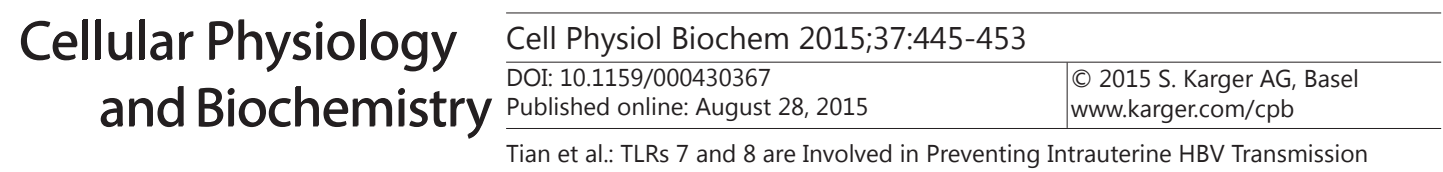

Table 2. Sequences of Primers

\begin{tabular}{|c|c|c|}
\hline Gene & Sequence ( $5^{\prime}$ to $\left.3^{\prime}\right)$ & Length \\
\hline \multirow[t]{2}{*}{ TLR7 } & Forward: GGAGGTATTCCCACGAACACC & $141 \mathrm{bp}$ \\
\hline & Reverse: TGACCCCAGTGGAATAGGTACAC & \\
\hline \multirow[t]{2}{*}{ TLR8 } & Forward: AAACTTGACCCAACTTCGATACCTAA & $101 \mathrm{bp}$ \\
\hline & Reverse: GATCCAGCACCTTCAGATGAGG & \\
\hline \multirow[t]{2}{*}{ MyD88 } & Forward: GTGCAGGAGATGATCCGGCA & $257 \mathrm{bp}$ \\
\hline & Reverse: TTCTGATGGGCACCTGGAGA & \\
\hline \multirow[t]{2}{*}{ IL-8 } & Forward: TTTTGCCAAGGAGTGCTAAAGA & $194 \mathrm{bp}$ \\
\hline & Reverse: AACССТCTGCACCСAGTTTTC & \\
\hline \multirow[t]{2}{*}{ IFN- $\alpha$} & Forward: TTTCTCCTGCCTGAAGGACAG & $373 b p$ \\
\hline & Reverse: GCTCATGATTTCTGCTCTGACA & \\
\hline \multirow[t]{2}{*}{ IFN- $\beta$} & Forward: GCCGCATTGACCATCTATGAGA & $346 b p$ \\
\hline & Reverse: GAGATCTTCAGTTTCGGAGGTAAC & \\
\hline \multirow[t]{2}{*}{$\beta$-actin } & Forward: AGAAAATCTGGCACCACACC & $173 \mathrm{bp}$ \\
\hline & Reverse: TAGCACAGCCTGGATAGCAA & \\
\hline
\end{tabular}

fluorescent protein (GFP) reporter gene driven by the U6 promoter. Three vectors were designed: LVMYD88-RNAi (8920-1), LV-MYD88- RNAi(8922-1), and LV-MYD88-RNAi (8923-1). The suppression of mRNA expression was analyzed by real-time reverse transcription-polymerase chain reaction (RT-PCR), and MyD88 protein levels were detected by Western blotting. The most efficient recombinant vector was used in later experiments. hU6-RNAi vector, which produces a non-targeting sequence TTC TCC GAA CGT GTC ACGT, was used as the negative control (GV248-NC). The recombinant vectors and the shRNA-LVs were co-transfected into $293 \mathrm{~T}$-cell, and the titer of recombinant lentivirus was $5 \mathrm{E}+7 \mathrm{TU}$.

HBV transcytosis study

To observe the effect of MyD88 siRNA on HBV translocation across trophoblastic cell barrier, an in vitro transcytosis study system was established and verified as described by Bhat et al [3]. Briefly, Swan 71 cells were seeded to a confluence of $60-70 \%$ on six-well PET cell culture inserts (Corning Inc., USA) in a twochamber system. HBV-positive serum $\left(10^{7}\right.$ copies of HBV) was added to the apical domain of the polarized monolayers when the corrected transepithelial resistance measurements exceeded $100 \Omega \mathrm{cm}^{2}$, and all of the apical and basolateral supernatant were collected respectively 48 hours later. The amount of HBV-DNA copies was determined with quantitative PCR.

Assays

Serum markers of hepatitis A, B, C and E including HAV IgM, HBsAg, HBeAg, anti-HBc, anti-HBe, HCV IgG and HEV IgM were routinely detected with enayme-linked immunoabsorbent assay (ELISA) (SinoAmerican Biotechnology Inc., Beijing, China) and HBV-DNA with real time PCR (Zhongshan University DaAn Gene Company, Zhongshan, China).

Total RNA was isolated by using the Trizol RNA reagent (Invitrogen Life Technologies, CA, USA). Reverse transcription was performed with random primers using PrimeScript RT reagent kit (Takara Bio Inc, Tokyo, Japan). The RNA and cDNA samples were stored at $-80^{\circ} \mathrm{C}$. The sequences of primers and PCR conditions for the detection of TLR7, TLR8 and the internal control genes were listed in Table 2. All primers were synthesized by Shanghai Sangong Biological Engineering Technology \& Services Co. Ltd (Shanghai, China). Real-time PCR was performed on the ABI7900 HT Fast real-time PCR System (Applied Biosystems, USA) using the SYBR(R) Premix EXTaq (Takara Bio Inc, Tokyo, Japan) according to the manufacturer's instructions. cDNA template of $2 \mu \mathrm{l}$ was used for each reaction in a system of $25 \mu \mathrm{l}$. All PCR reactions were performed in triplicate. Thermal cycling conditions included pre-incubation at $95^{\circ} \mathrm{C}$ for $10 \mathrm{~min}$ followed by 40 cycles of $95^{\circ} \mathrm{C}$ for $15 \mathrm{~s}, 60^{\circ} \mathrm{C}$ for $30 \mathrm{sec}$ and $72^{\circ} \mathrm{C}$ for $10 \mathrm{~s}$. LightCycler collected data automatically and analyzed the value of Threshold Cycle (Ct). The fold changes of mRNA expression were detected by using $2^{-\Delta \Delta C t}$ method.

\section{Statistical analysis}

Data distribution was tested with Kolmogorov-Smirnov test and data were presented in mean and SD or median and quartiles according to their distribution. Significance was tested with one-way ANOVA, 


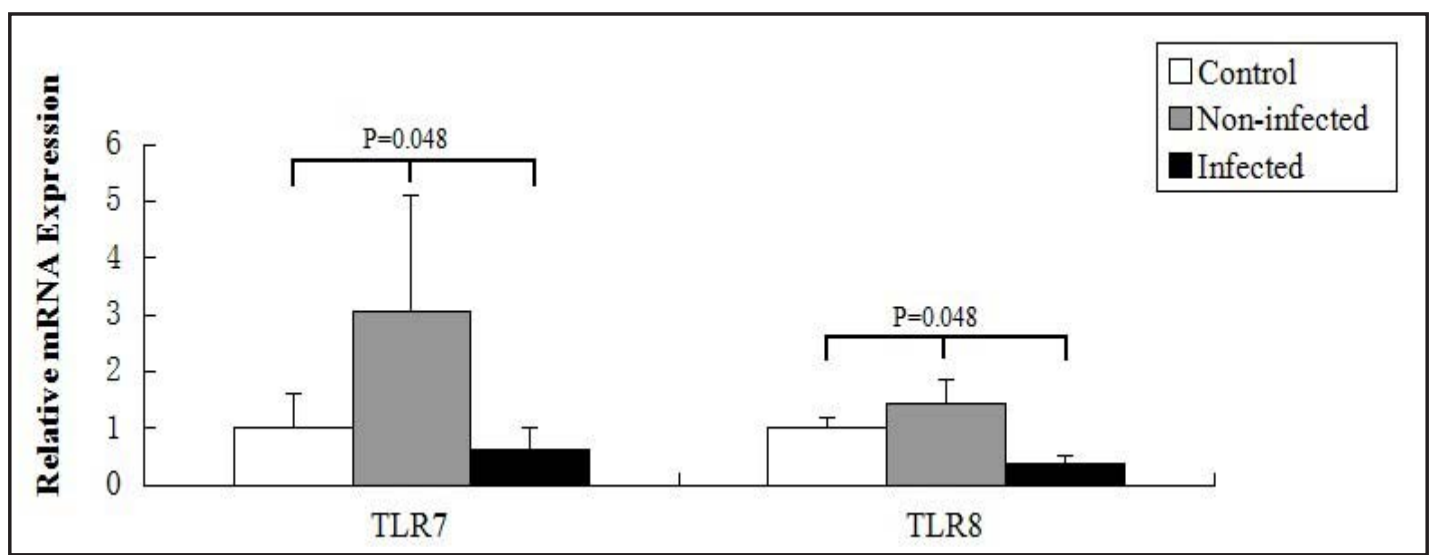

Fig. 1. Comparison of the expression of TLR7 and TLR8 in placenta. The relative expression of TLR7 and TLR8 was determined with quantitative PCR in placenta of HBV-negative women (control) and HBV-positive women whose infants were infected via intrauterine transmission (infected) or not (non-infected). The expression of TLR7 and TLR8 were significantly different among control, non-infected and infected groups $(\mathrm{P}=0.048$ for both). The expression of TLR7 was significantly higher in non-infected group than infected group $(\mathrm{P}=0.039)$ and control $(\mathrm{P}=0.043)$. TLR8 expression was significantly higher in non-infected group than control $(\mathrm{P}=0.014)$.

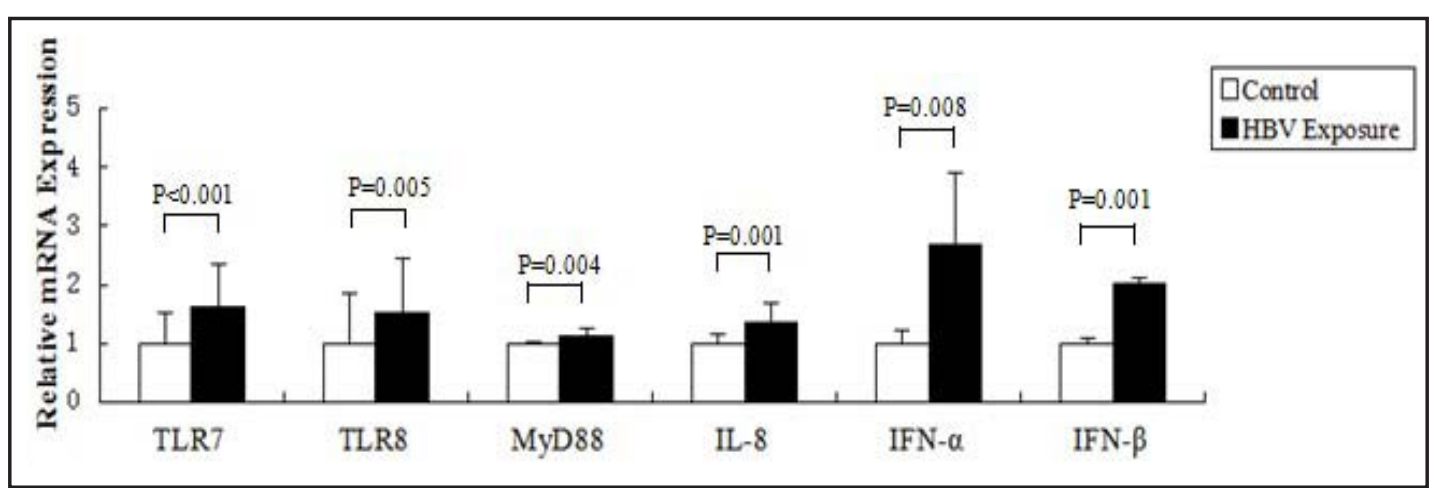

Fig. 2. The effects of HBV exposure on the expression of TLR7, TLR8 and downstream molecules. The expression of TLR7, TLR8, MyD88, IL-8, IFN- $\alpha$ and IFN- $\beta$ was significantly increased when trophoblast cells exposed to HBV.

Student $t$ test, Mann-Whitney test or Chi-square test where appropriate. SPSS statistic package (SPSS Company, Chicago, IL, USA) was used for data analysis.

\section{Results}

As shown in Fig. 1, there were significant differences in placental mRNA expression of TLR7 ( $\mathrm{F}=3.263, \mathrm{P}=0.048)$ and TLR8 ( $\mathrm{F}=3.257, \mathrm{P}=0.048)$ among the three groups. The expression of TLR7 mRNA was significantly higher in non-infected group than infected group $(\mathrm{P}=0.039)$ and control $(\mathrm{P}=0.043)$. There was a significant difference in TLR8 expression between non-infected group and control $(\mathrm{P}=0.014)$, and the difference was close to but not significant $(\mathrm{P}=0.074)$ between non-infected and infected groups.

To determine if HBV up-regulates the expression of TLR7, TLR8 and downstream molecules, Swan 71 cells were cultured in the absence (control) or presence (HBV exposure) of HBV and detected the expression of TLR7, TLR8, MyD88, interferon (IFN)- $\alpha$, IFN- $\beta$ and interleukin-8 (IL-8) mRNA. We found significant increases in mRNA levels of TLR7 $(\mathrm{P}<0.001)$, 
Fig. 3. The effect of MyD88 siRNA. The expression of MyD88 was significantly decreased $(\mathrm{P}=0.04)$ when MyD88 was interfered by siRNA.

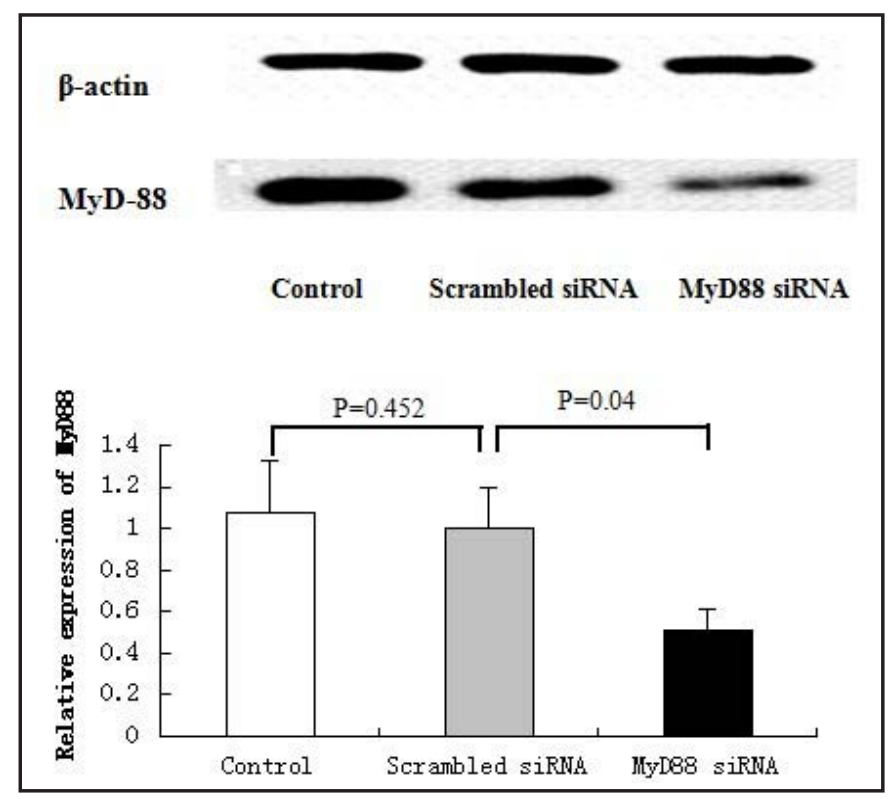

Fig. 4. The effect of MyD88 siRNA on the expression of IFN- $\alpha$, IFN- $\beta$ and IL- 8 and HBV transcytosis. The silence of MyD88 significantly reduced the expression of IFN- $\alpha \quad(\mathrm{P}<0.001), \quad$ IFN- $\beta$ $(\mathrm{P}=0.01)$ and IL-8 $(\mathrm{P}<0.001)$ but significantly increased $(\mathrm{P}=0.03)$ the amount of HBV transcytosed across trophoblastic monolayer.

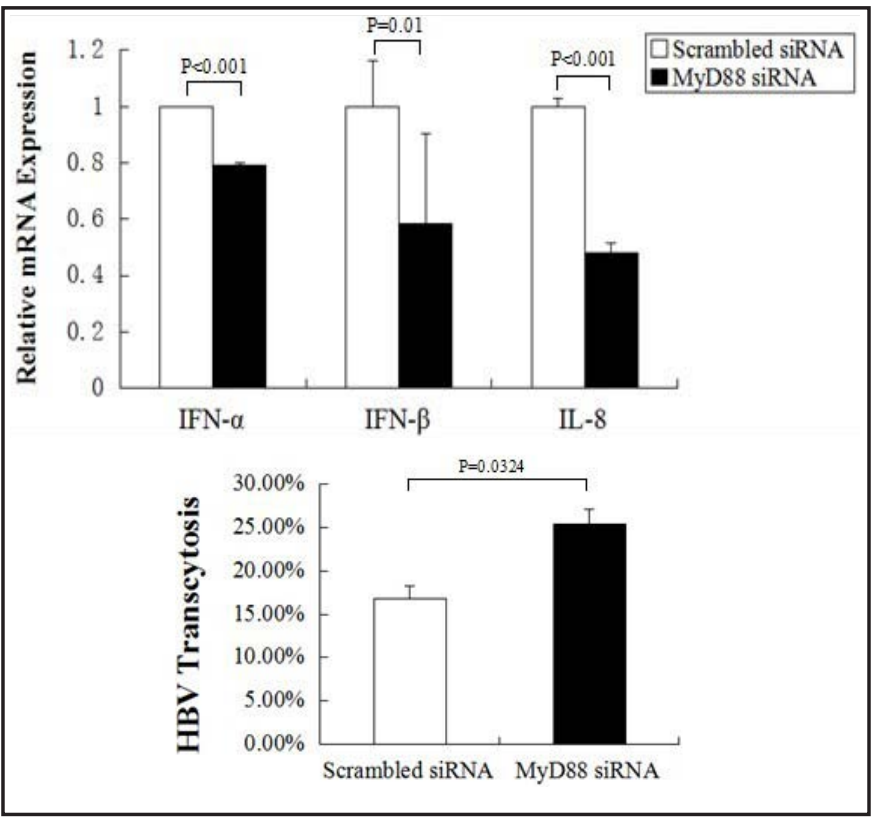

TLR8 ( $\mathrm{P}=0.005)$, MyD88 ( $\mathrm{P}=0.004)$, IFN- $\alpha(\mathrm{P}=0.004)$, IFN- $\beta(\mathrm{P}<0.001)$ and IL-8 $(\mathrm{P}=0.001)$ when trophoblast cells exposed to HBV compared to control (Fig. 2). When MyD88 was silenced by siRNA, the expression of MyD88 protein was significantly reduced $(\mathrm{P}=0.04)$ (Fig. 3), the expression of IFN- $\alpha(\mathrm{P}<0.001)$, IFN- $\beta(\mathrm{P}=0.01)$ and IL-8 $(\mathrm{P}<0.001)$ decreased significantly while the amount of HBV transcytosed across trophoblastic monolayer increased significantly ( $\mathrm{P}=0.03$ ) (Fig. 4).

\section{Discussion}

As a pattern recognition receptor, TLR recognizes and responds to HBV. It has been reported that TLR signaling inhibits HBV replication in vivo and in vitro. Isogawa et al [15] showed HBV replication was almost completely abolished in HBV transgenic mice by administration of a single intravenous injection of ligands specific for TLR3, TLR4, TLR5, TLR7, or TLR9 within 24 hours in an IFN-dependent manner. In vitro, supernatants of TLR3 KARGER 
or TLR4-stimulated murine Kupffer cells (KCs) and TLR4-stimulated sinusoidal endothelial cells (LSECs) suppressed HBV replication in HBV-Met cells [16]. In hepatoma cell HepG2, Xia et al [17] observed that TLR2, 3, 4, 7, 9 and MyD88 were abundantly expressed, and activation of these TLRs induced apparent production of antiviral cytokines including IFN- $\alpha$ and $\beta$ and inhibited HBV replication. Further, the over-expression of MyD88 which is the universal adaptor for all TLRs with the except for TLR3 induced antiviral response and inhibited HBV replication in HepG2 and Huh7 cells [18]. In addition, the expressions of TLR7 [19], TLR9 [19, 20] and signaling molecules (IRAK1, IRAK4, TRAF3 and IRF7) [21] were significantly decreased in PBMC of chronic HBV infected subjects compared with control. These findings indicate that TLRs and its induced responses play important roles in the progress of HBV infection.

Placental trophoblast expresses functional TLRs. It has been reported that normal placental tissue expresses TLR1-10 at the mRNA level [8]. At the protein level, TLR2 and TLR4 are expressed in term placenta, however, there are contradictory findings in cellular localization of TLR4 [8]. Following ligation of TLR2 or TLR4 by zymosan or LPS, trophoblast cells from term placental explants can produce IL-6, IL-8, nitric oxide which has potent antimicrobial properties $[22,23]$. Studies on first trimester trophoblast cells have shown that treatment with LPS induces the production of granulocyte colony stimulating factor (G-CSF) and regulated uponactivation normal $\mathrm{T}$ cell expressed and secreted factor (RANTES) [24]. Messenger RNA of TLR1-10 is expressed on human chorioncarcinoma cell lines. Lipopolysaccharide (LPS) and DNA oligonucleotides containing unmethylated CpG motifs (CpG) induced the enhanced expression of TLR2 mRNA and TLR2 surface protein, activated signaling components (NF-kappa B, the phosphorylation of ERK1/2 and p38 MAP kinases) and increased the secretion of interleukin-8 [25]. Taken together, these findings suggest that trophoblast cells function similarly as immune cells and are able to recognize and respond to the pathogens at the maternal-fetal interface.

However, the study on the roles of placental TLRs in the prevention of intrauterine transmission of HBV is still little. In the current investigation, we described for the first time that placental expression of TLR7 and 8 was markedly increased in HBV-positive women (in vivo) and the in vitro exposure to HBV enhanced the expression of TLR7 and 8 as well as signaling molecule and antiviral cytokines of trophoblastic cell, indicating that TLR7 and 8 on trophoblasts function in a pattern similar to immune cells in recognizing and responding to HBV. We also revealed that the up-regulation in the expression of TLR7 and 8 was absent in the placenta of women whose infants were infected via intrauterine transmission, and silence of MyDD88 decreased the expression of antiviral cytokines and increased the amount of HBV translocating trophoblastic barrier, implying TLR and downstream molecules are involved in the prevention of intrauterine transmission of HBV. Given that placenta is the pregnancy-specific component of innate immune system [5] and TLRs and their downstream events are important part of innate immune system[3, 4, 7-9, 11, 13, 15, 22], our findings suggest that immune response to HBV by placental trophoblast is central in preventing intrauterine infection of HBV and up-regulation of TLR7 and TLR8 expression is part of the immune response to $\mathrm{HBV}$ infection.

\section{Conclusions}

In summary, toll-like receptor and mediated inflammatory response are necessary for the prevention of intrauterine HBV transmission and absence of TLR-mediated response to $\mathrm{HBV}$ is one of the mechanisms leading to $\mathrm{HBV}$ infection via intrauterine route.

\section{Abbreviations}

HBV (hepatitis B virus); TLR (toll-like receptor); PCR (poly-chain reaction); siRNA(small interfering RNA); IFN (interferon); IL (interleukin); PAMPs (pathogen-associated molecular patterns); NF- $\kappa B$ (nuclear factor $\kappa B$ ); HBsAg (hepatitis B surface antigen); HIV (human immunodeficiency virus); HBIg (human hepatitis B immunoglobing). 


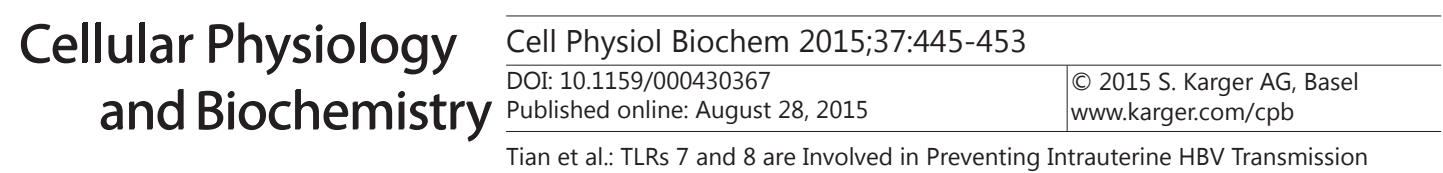

\section{Acknowledgements}

This study was funded by Natural Science Foundation of Zhejiang Province (Y2100416) and Natural Science Foundation of China (81170572, 81370726 and 81300501).

\section{Disclosure Statement}

The authors declare that they have no competing interests

\section{References}

1 Lavanchy D: Hepatitis b virus epidemiology, disease burden, treatment, and current and emerging prevention and control measures. J Viral Hepat 2004;11:97-107.

2 Guo Z, Shi XH, Feng YL, Wang B, Feng LP, Wang SP, Zhang YW: Risk factors of hbv intrauterine transmission among hbsag-positive pregnant women. J Viral Hepat 2013;20:317-321.

3 Bhat P, Anderson DA: Hepatitis b virus translocates across a trophoblastic barrier. J Virol 2007;81:72007207.

4 Bai H, Zhang L, Ma L, Dou XG, Feng GH, Zhao GZ: Relationship of hepatitis b virus infection of placental barrier and hepatitis b virus intra-uterine transmission mechanism. World J Gastroenterol 2007;13:36253630.

5 Guleria I, Pollard JW: The trophoblast is a component of the innate immune system during pregnancy. Nat Med 2000;6:589-593.

6 Kim YM, Romero R, Chaiworapongsa T, Kim GJ, Kim MR, Kuivaniemi H, Tromp G, Espinoza J, Bujold E, Abrahams VM, Mor G: Toll-like receptor-2 and -4 in the chorioamniotic membranes in spontaneous labor at term and in preterm parturition that are associated with chorioamnionitis. Am J Obstet Gynecol 2004;191:1346-1355.

7 Abrahams VM, Visintin I, Aldo PB, Guller S, Romero R, Mor G: A role for tlrs in the regulation of immune cell migration by first trimester trophoblast cells. J Immunol 2005;175:8096-8104.

8 Abrahams VM, Mor G: Toll-like receptors and their role in the trophoblast. Placenta 2005;26:540-547.

9 Delorme-Axford E, Donker RB, Mouillet JF, Chu T, Bayer A, Ouyang Y, Wang T, Stolz DB, Sarkar SN, Morelli AE, Sadovsky Y, Coyne CB: Human placental trophoblasts confer viral resistance to recipient cells. Proc Natl Acad Sci U S A 2013;110:12048-12053.

10 Kawai T, Akira S: Pathogen recognition with toll-like receptors. Curr Opin Immunol 2005;17:338-344.

11 Kawai T, Akira S: Toll-like receptor downstream signaling. Arthritis Res Ther 2005;7:12-19.

12 Zarember KA, Godowski PJ: Tissue expression of human toll-like receptors and differential regulation of toll-like receptor mrnas in leukocytes in response to microbes, their products, and cytokines. J Immunol 2002;168:554-561.

13 Akira S, Takeda K: Toll-like receptor signalling. Nat Rev Immunol 2004;4:499-511.

14 Takeda K, Akira S: Tlr signaling pathways. Semin Immunol 2004;16:3-9.

15 Isogawa M, Robek MD, Furuichi Y, Chisari FV: Toll-like receptor signaling inhibits hepatitis b virus replication in vivo. J Virol 2005;79:7269-7272.

16 Wu J, Lu M, Meng Z, Trippler M, Broering R, Szczeponek A, Krux F, Dittmer U, Roggendorf M, Gerken G, Schlaak JF: Toll-like receptor-mediated control of hbv replication by nonparenchymal liver cells in mice. Hepatology 2007;46:1769-1778.

17 Xia C, Lu M, Zhang Z, Meng Z, Shi C: Tlrs antiviral effect on hepatitis b virus in hepg2 cells. J Appl Microbiol 2008;105:1720-1727.

18 Guo H, Jiang D, Ma D, Chang J, Dougherty AM, Cuconati A, Block TM, Guo JT: Activation of pattern recognition receptor-mediated innate immunity inhibits the replication of hepatitis $b$ virus in human hepatocyte-derived cells. J Virol 2009;83:847-858.

19 Xu N, Yao HP, Sun Z, Chen Z: Toll-like receptor 7 and 9 expression in peripheral blood mononuclear cells from patients with chronic hepatitis b and related hepatocellular carcinoma. Acta Pharmacol Sin 2008;29:239-244. 


\section{Cellular Physiology Cell Physiol Biochem 2015;37:445-453 \begin{tabular}{l|l|l|}
\cline { 2 - 2 } DOI: 10.1159/000430367 & (0) 2015 S. Karger AG, Basel \\
\hline
\end{tabular} \\ Tian et al.: TLRs 7 and 8 are Involved in Preventing Intrauterine HBV Transmission}

20 Zhou J, Huang Y, Tian D, Xu D, Chen M, Wu H: Expression of toll-like receptor 9 in peripheral blood mononuclear cells from patients with different hepatitis b and c viral loads. J Huazhong Univ Sci Technolog Med Sci 2009;29:313-317.

21 Momeni M, Zainodini N, Bidaki R, Hassanshahi G, Daneshvar H, Khaleghinia M, Ebrahim M, KarimiGoogheri M, Askari A, Arababadi MK, Kennedy D: Decreased expression of toll like receptor signaling molecules in chronic hbv infected patients. Hum Immunol 2014;75:15-19.

22 Holmlund U, Cebers G, Dahlfors AR, Sandstedt B, Bremme K, Ekstrom ES, Scheynius A: Expression and regulation of the pattern recognition receptors toll-like receptor-2 and toll-like receptor-4 in the human placenta. Immunology 2002;107:145-151.

23 Nakatsuka M, Asagiri K, Noguchi S, Habara T, Kudo T: Nafamostat mesilate, a serine protease inhibitor, suppresses lipopolysaccharide-induced nitric oxide synthesis and apoptosis in cultured human trophoblasts. Life Sci 2000;67:1243-1250.

24 Svinarich DM, Bitonti OM, Araneda H, Romero R, Gonik B: Induction and postranslational expression of g-csf and rantes in a first trimester trophoblast cell line by lipopolysaccharide. Am J Reprod Immunol 1996;36:256-259.

25 Klaffenbach D, Rascher W, Rollinghoff M, Dotsch J, Meissner U, Schnare M: Regulation and signal transduction of toll-like receptors in human chorioncarcinoma cell lines. Am J Reprod Immunol 2005;53:77-84. 